\title{
Distribution of plasma cells and other cells containing immunoglobulin in the respiratory tract in chronic bronchitis
}

\author{
C. A. SOUTAR ${ }^{1}$ \\ From the Cardiothoracic Institute, Brompton Hospital, London
}

\begin{abstract}
Soutar, C. A. (1977). Thorax, 32, 387-396. Distribution of plasma cells and other cells containing immunoglobulin in the respiratory tract in chronic bronchitis A study of the distribution of cells containing immunoglobulin in the respiratory tract in chronic bronchitis has been carried out on necropsy tissues from six subjects who died from complications of severe chronic obstructive bronchitis and five subjects with 'incidental' chronic bronchitis who died from unrelated disease. The results have been compared with previous reported findings in normal subjects.

There was a deficiency of IgA cells in all six subjects with fatal chronic bronchitis when compared with normal subjects. The IgA cell counts in the subjects with 'incidental' chronic bronchitis corresponded to normal values for healthy non-smokers and did not share the increased cell counts in lower lobe bronchus occurring in healthy smokers.

This work suggests that subjects who die from chronic obstructive bronchitis are deficient in plasma and other cells containing $\operatorname{IgA}$ in the respiratory tract, and that subjects with 'incidental' chronic bronchitis are normal in this respect.

A preliminary study in which local bronchial secretion of $\operatorname{IgA}$ was estimated in the sputum of patients with severe chronic obstructive bronchitis showed that bronchial IgA secretion appeared to be low during acute infections in five out of 14 patients. This finding is consistent with the hypothesis that bronchial $\operatorname{IgA}$ secretion is impaired in a proportion of patients with severe chronic bronchitis.
\end{abstract}

Chronic bronchitis is frequently accompanied by recurrent or chronic bronchial infection (Oswald et al., 1953; Fry, 1954). This susceptibility may be the result of mechanical factors such as the difficulty in clearing sticky mucus from small airways or impairment of ciliary clearance of microorganisms from the bronchial tree, but there is also interest in immunological mechanisms such as macrophage function and in possible defects of the local production of specific antibody to microorganisms.

The serum $\operatorname{IgA}$ and IgG in almost all subjects with chronic bronchitis tends to be normal or raised (Biegel and Krumholz, 1968; Falk et al., 1970). Attempts have been made to estimate local secretion of immunoglobulin into the bronchi by 'Present address: University of Illinois Medical Center, Chicago, Ill.,
60680 USA measurement of $\operatorname{IgG}$ and $\operatorname{IgA}$ in the sputum of bronchitic patients, but the results have been conflicting (Falk et al., 1972; Medici and Buergi, 1971). The lack of agreement may be due to selection of chronic bronchitics with disease of different severity, varying contamination of sputum with saliva, and serum exudation from inflamed mucosal surfaces.

A more direct quantitative approach, counting the number of cells containing immunoglobulin in necropsy bronchial tissues stained by immunofluorescent methods, has therefore been undertaken in subjects suffering from chronic bronchitis. Results in normal subjects have recently been reported (Soutar, 1976).

Preliminary studies of bronchial IgA secretion in a small number of subjects with severe chronic bronchitis are also reported. 


\section{Subjects}

Necropsy material was obtained from 11 subjects known to have suffered from chronic bronchitis (MRC, Committee on the Aetiology of Chronic Bronchitis, 1965), and medical histories were obtained from hospital notes, the general practitioners, and relatives. Six of these subjects were known to have suffered from chronic bronchitis for many years and had died in hospital after being admitted for exacerbations of the disease ('fatal' chronic bronchitis).

These subjects all had severe irreversible airways obstruction and suffered from frequent chest infections. Three subjects $(18,19,20)$ had radiographic evidence of severe emphysema (Simon, 1971), and one of these was known to have alpha1-antitrypsin deficiency (subject 19). Even in those with emphysema, chronic cough and expectoration were prominent, and bronchial mucous gland hypertrophy was found.
A further five subjects were reported by their relatives to have had chronic cough and sputum but had never complained to their general practitioners of dyspnoea or frequent chest infection (except subjects 10 and 11 whose heart disease appeared to be the cause of their dyspnoea). They died from causes unrelated to respiratory disease, and their respiratory function had not been measured. The cases were consecutive as far as possible. (Clinical details are set out in Tables 1 and 2.) None was taking anticonvulsants.

\section{Material and methods}

Tissue blocks from the upper one-third of the trachea, right main bronchus close to the carina, right lower lobe bronchus, and peripheral lung were snap frozen and stored at $-70^{\circ} \mathrm{C}$ until required. Adjacent tissue blocks were fixed in buffered formol saline.

Table 1 'Fatal' chronic bronchitis

\begin{tabular}{|c|c|c|c|c|c|c|}
\hline Subject (sex) & Age & $\begin{array}{l}\text { Smoking } \\
\text { history }\end{array}$ & $\begin{array}{l}\text { Cough } \\
\text { history }\end{array}$ & $\begin{array}{l}F E V_{1} \\
(m l)\end{array}$ & Cause of death & $\begin{array}{l}\text { Interval between death } \\
\text { and fixation of tissue }\end{array}$ \\
\hline $15(\mathrm{M})$ & 66 & $\begin{array}{l}40-60 / \text { day for } \\
30 \text { years, only snuff } \\
\text { for last } 8 \text { years }\end{array}$ & $\begin{array}{l}\text { Chronic cough } \\
\text { and sputum for } \\
20 \text { years }\end{array}$ & 550 & $\begin{array}{l}\text { Respiratory and } \\
\text { cardiac failure }\end{array}$ & 12 hours \\
\hline $16(M)$ & 50 & $\begin{array}{l}20 \text { cigs/day for } \\
25 \text { years, } 10 / \text { day } \\
\text { for last } 10 \text { years }\end{array}$ & $\begin{array}{l}\text { Chronic cough } \\
\text { and sputum for } \\
20 \text { years }\end{array}$ & 600 & $\begin{array}{l}\text { Respiratory and } \\
\text { cardiac failure }\end{array}$ & 12 hours \\
\hline $17(\mathrm{M})$ & 64 & $\begin{array}{l}40 \text { cigs/day for } \\
30 \text { years, none for } \\
\text { last } 10 \text { years }\end{array}$ & $\begin{array}{l}\text { Chronic cough } \\
\text { and sputum for } \\
20 \text { years }\end{array}$ & 800 & $\begin{array}{l}\text { Respiratory and } \\
\text { cardiac failure }\end{array}$ & 40 hours \\
\hline 18 (F) & 51 & $\begin{array}{l}20 \text { cigs/day for } \\
30 \text { years right up } \\
\text { to last illness }\end{array}$ & $\begin{array}{l}\text { Chronic cough } \\
\text { and sputum for } \\
15 \text { years }\end{array}$ & 450 & Respiratory failure & 40 hours \\
\hline $19(\mathrm{M})$ & 54 & $\begin{array}{l}20 \text { cigs/day for } \\
20 \text { years, none for } \\
15 \text { years }\end{array}$ & $\begin{array}{l}\text { Chronic cough } \\
\text { and sputum for } \\
30 \text { years }\end{array}$ & 450 & $\begin{array}{l}\text { Respiratory and } \\
\text { cardiac failure }\end{array}$ & 48 hours \\
\hline $20(M)$ & 48 & Never smoked & $\begin{array}{l}\text { Chronic cough } \\
\text { and sputum for } \\
20 \text { years }\end{array}$ & 400 & Respiratory failure & 16 hours \\
\hline
\end{tabular}

Table 2 'Incidental' chronic bronchitis

\begin{tabular}{|c|c|c|c|c|c|c|}
\hline Subject (sex) & Age & $\begin{array}{l}\text { Smoking } \\
\text { history }\end{array}$ & $\begin{array}{l}\text { Cough } \\
\text { history }\end{array}$ & $\begin{array}{l}F E V_{1} \\
(m l)\end{array}$ & Cause of death & $\begin{array}{l}\text { Interval between death } \\
\text { and fixation of tissue }\end{array}$ \\
\hline $10(\mathrm{M})$ & 51 & $\begin{array}{l}35 \text { cigs/day for } \\
30 \text { years }\end{array}$ & $\begin{array}{l}\text { Chronic cough } \\
\text { and sputum for } \\
15 \text { years }\end{array}$ & $\begin{array}{l}\text { Not } \\
\text { known }\end{array}$ & $\begin{array}{l}\text { Ischaemic heart } \\
\text { disease }\end{array}$ & 48 hours \\
\hline $11(\mathrm{M})$ & 62 & $\begin{array}{l}30-40 / \text { day for } \\
40 \text { years }\end{array}$ & $\begin{array}{l}\text { Chronic cough } \\
\text { and sputum for } \\
10 \text { years }\end{array}$ & $\begin{array}{l}\text { Not } \\
\text { known }\end{array}$ & $\begin{array}{l}\text { Ischaemic heart } \\
\text { disease }\end{array}$ & 72 hours \\
\hline $12(\mathrm{M})$ & 64 & $\begin{array}{l}30 \text { cigs/day for } \\
30 \text { years }\end{array}$ & $\begin{array}{l}\text { Chronic cough } \\
\text { and sputum for } \\
20 \text { years }\end{array}$ & $\begin{array}{l}\text { Not } \\
\text { known }\end{array}$ & $\begin{array}{l}\text { Ruptured } \\
\text { abdominal } \\
\text { aneurysm }\end{array}$ & 48 hours \\
\hline $13(\mathrm{M})$ & 66 & $\begin{array}{l}60 \text { cigs/day for } \\
40 \text { years, } 20 / \text { day } \\
\text { for last } 10 \text { years }\end{array}$ & $\begin{array}{l}\text { Chronic cough } \\
\text { and sputum for } \\
20 \text { years }\end{array}$ & $\begin{array}{l}\text { Not } \\
\text { known }\end{array}$ & $\begin{array}{l}\text { Head injuries } \\
\text { (death } \\
\text { instantaneous) }\end{array}$ & 36 hours \\
\hline $14(F)$ & 55 & $\begin{array}{l}30 \text { cigs/day for } \\
30 \text { years, gave up } \\
5 / 12 \text { before death }\end{array}$ & $\begin{array}{l}\text { Chronic cough } \\
\text { and sputum for } \\
10 \text { years }\end{array}$ & $\begin{array}{l}\text { Not } \\
\text { known }\end{array}$ & $\begin{array}{l}\text { Barbiturate } \\
\text { poisoning }\end{array}$ & 48 hours \\
\hline
\end{tabular}




\section{IMMUNOFLUORESCENT STAINS}

A single layer immunofluorescent method was used to detect immunoglobulin in $5 \mu$ cryostat sections of the frozen tissues. The sections of airway included the whole circumference, and all sections were cut as serially as the method allowed. The sections were washed before being stained but irrigation of sections containing cartilage during washing was kept to a minimum to avoid dislodging them. The antisera, raised in goats against human serum IgA, IgG, IgM, and IgE, were obtained from Hyland Laboratories and were conjugated with fluorescein isothiocyanate in this laboratory. Fluorescein/protein ratios lay between $1: 2$ and $1: 4$. Conjugates were absorbed with pig liver powder before use. Potency and specificity of the antisera were confirmed by immunodiffusion and immunoelectrophoresis and further checked by staining of rat liver previously incubated with human sera containing antinuclear antibody of known immunoglobulin class (for which I am indebted to Dr. P. Haslam). By these methods the antisera against IgG, IgA, and IgM were shown to be potent and highly specific. Using a radio-labelled preparation of an antiserum to goat serum to visualise lines of precipitation produced by immunoelectrophoresis of human serum rich in IgE against the specific antisera, it was possible to show that the antiserum to human IgE was potent but did contain some weak activity against IgG. IgE cell counts may, therefore, have been increased by the inclusion of cells containing IgG, but these results have been included as they provide useful maximum figures. Positive results were confirmed by blocking with unconjugated antisera.

\section{READING OF SECTIONS}

Near serial sections were stained by the monospecific antisera in sequence. They were read out of order by an observer who was unaware of the antiserum applied and from which of two or three tissue blocks the sections were taken. The cell counts were performed by scanning systematically with the aid of a parallel line graticule until the whole of the wall of the airway had been surveyed. All recognisable cells whose cytoplasm was stained by the antiserum, except epithelial cells, were counted. Counts were performed on 16 sections at each tissue site, four sections for each antiserum. Sections from normal subjects previously reported (Soutar, 1976) were included in the same batches and read in parallel with those from the bronchitics to minimise observer bias. The total number of sections examined approached 500, not including the normal subjects. For statistical study analysis of variance was applied to square roots of the cell counts. Untransformed data are given in the text and tables and figures.

\section{SECTIONS OF PERIPHERAL LUNG}

It was possible to wash these sections more thoroughly than those containing cartilage. No formal counts were made of plasma cells in the bronchioles or air spaces, but the appearances were noted.

\section{FORMALIN-FIXED TISSUES}

Paraffin sections of formalin-fixed tissues adjacent to those examined by immunofluorescence were stained by haematoxylin and eosin to examine general tissue morphology and the presence of eosinophils and methyl green pyronine to visualise the plasma cells. The mucus gland/bronchial wall ratios were measured according to Reid (1960).

\section{ESTIMATION OF SPUTUM IgA}

Further evidence of a defect of bronchial $\operatorname{IgA}$ secretion in severe chronic bronchitis was sought by estimation of $\operatorname{IgA}$ in sputum. As a preliminary study, 57 sputum samples were collected at random intervals from 14 subjects suffering from long-standing chronic bronchitis who had severe airways obstruction $\left(\mathrm{FEV}_{1}<800 \mathrm{ml}\right)$ and who had been admitted to hospital for an exacerbation of their symptoms. Three of these subjects $(1,4,14)$ died of respiratory failure during that hospital admission, and a further four $(6,7,8,13)$ died within nine months. No necropsy studies were carried out. In three subjects, who were artificially ventilated, bronchial aspirate was obtained.

Sputum samples were diluted with and dialysed against distilled water, the gel was separated by centrifugation and discarded, and the supernatant lyophilised (Biserte et al., 1963). The powder was reconstituted at $2.5 \mathrm{mg} / \mathrm{ml}$ and IgA, IgG, and albumin were estimated by immunodiffusion on low-level plates (Beringwerke) using serum standards. The serum immunoglobulins were estimated in the routine hospital laboratory by radial immunodiffusion (Macini et al., 1965) and albumin by bromocresyl green binding (Northam and Widdowson, 1967). The proportions of $\operatorname{IgA}$ in sputum derived from active bronchial secretion or passively from serum were calculated using the formula of Deuschl and Johannson (1974) as follows: 


$$
\text { Local IgA secretion }=\frac{\text { Total sputum IgA }-\left(\text { serum IgA } \times \frac{\text { sputum albumin }}{\text { serum albumin }}\right)}{\text { Total sputum IgA }} \times 100 \%
$$

\section{Results}

GENERAL APPEARANCES

Plasma cells and other cells containing immunoglobulin were most plentiful in bronchial or tracheal submucous gland but were also present in the lamina propria of the bronchial epithelium. In most of the subjects with 'fatal' chronic bronchitis there was a striking lack of IgA cells in all sites (Fig. 1), so that the usual predominance of IgA over other immunoglobulin classes was much reduced. The cells which were present were almost universally small with scanty cytoplasm.

By contrast, the five subjects with 'incidental' chronic bronchitis had plentiful IgA cells in the trachea, main bronchus, and lower lobe bronchus (Fig. 2), although these cells appeared to be scantier than normal round small bronchi and bronchioles in peripheral lung sections. None was seen in alveolar walls. In the upper trachea the cells, were of the small variety, but in the main and lobar bronchus three of these subjects had large cells with plentiful cytoplasm, while the other two subjects had small cells.

\section{CELL COUNTS}

Consistency

Counts within each group of four sections were consistent, the variance between the slides within subjects being much less than the variance between subjects $(\mathrm{P}<0.001)$.

\section{Iga CELL COUNTS}

Mean $\operatorname{IgA}$ cell counts in the upper trachea, right main bronchus, and right lower lobe bronchus in six subjects with 'fatal' chronic bronchitis and five subjects with 'incidental' chronic bronchitis are set out in Table 3 and illustrated in Figure 3. The 'fatal' bronchitics have lower IgA counts than the 'incidental' chronic bronchitics in all three sites $(\mathrm{P}<0.05$ in trachea, and $\mathrm{P}<0.01$ in main and lobar bronchi).

Comparison with the normal subjects reported previously (Soutar, 1976) shows that the fatal chronic bronchitics have significantly lower IgA cell counts than normals in trachea $(P<0.05)$, main bronchus $(\mathrm{P}<0.01)$, and lobar bronchus $(\mathrm{P}<0.05)$.

Comparison of subjects with 'incidental' bronchitis shows that the $\operatorname{IgA}$ counts were in the same range as those of normal non-smokers at all three sites, and the same as those of normal smokers in the trachea and main bronchus, although in the lobar bronchus the cell counts were somewhat lower than in normal smokers, and this difference approached significance $(P<0.1>0.05)$ (Fig. 4). One normal non-smoker had cell counts

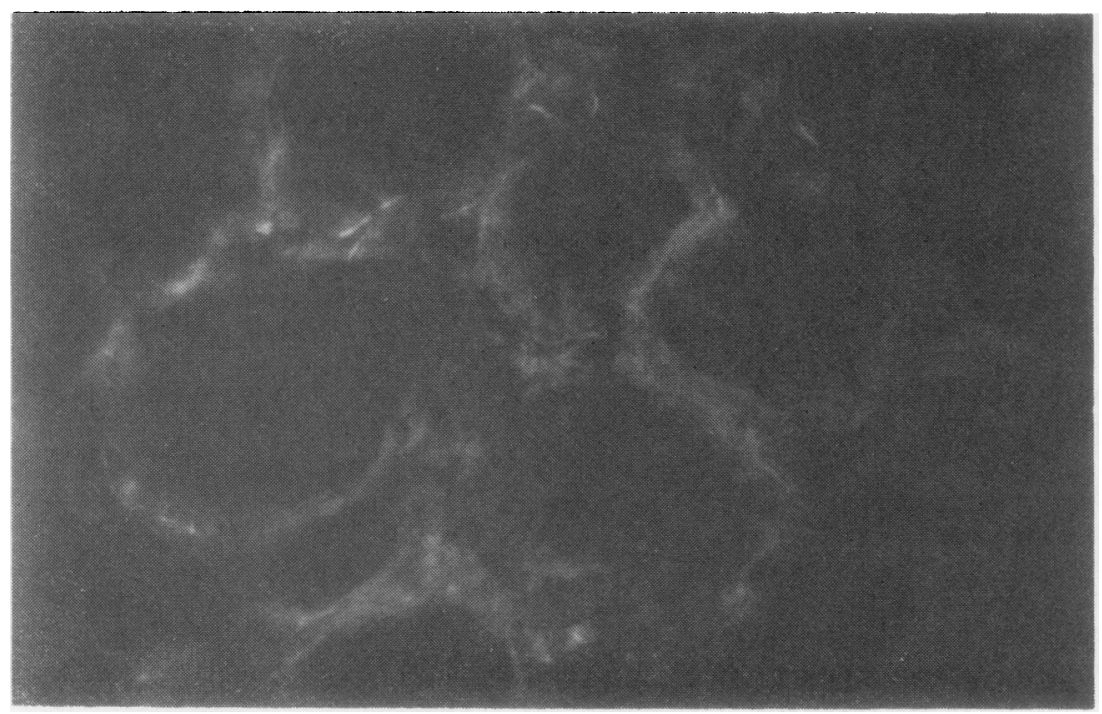

Fig. 1 Bronchial submucous gland in 'fatal' chronic bronchitic subject-IgA plasma cells small and infrequent $(\times 400)$. 


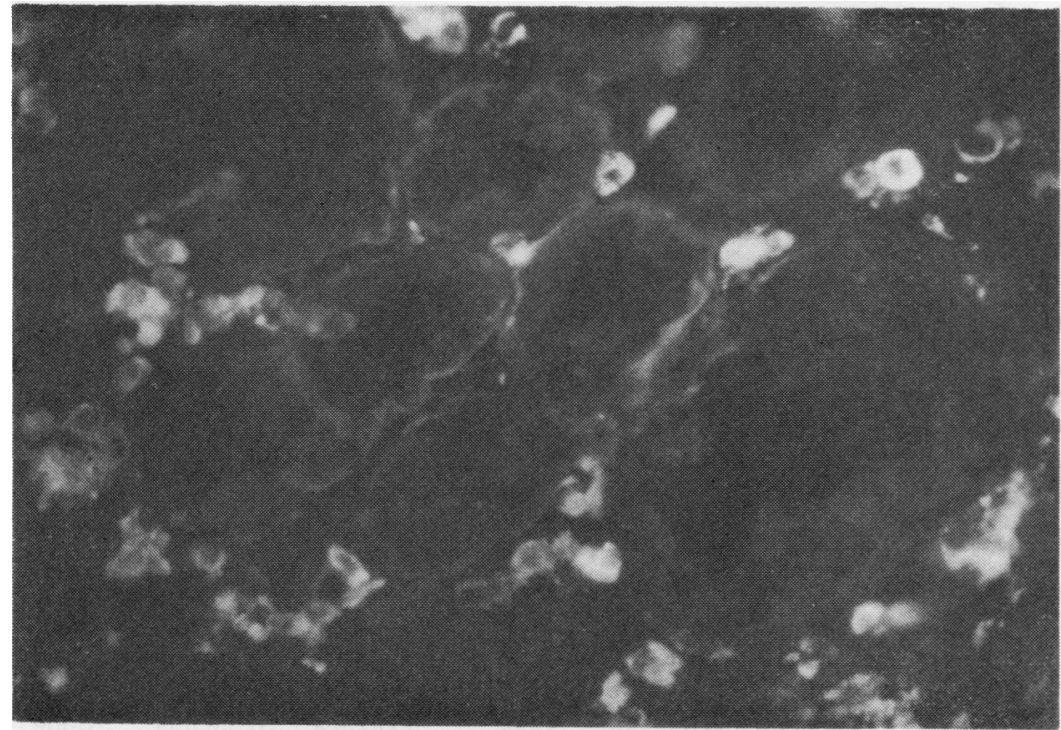

Fig. 2 Bronchial submucous gland in 'incidental' bronchitic subject-IgA plasma cells large and numerous $(\times 400)$.

Table 3 Mean IgA cell counts (cells per $5 \mu$ section) in five subjects with 'incidental' chronic bronchitis (10-14) and six subjects with 'fatal' chronic bronchitis (15-20)

\begin{tabular}{lccll}
\hline Subject & $\begin{array}{l}\text { Upper } \\
\text { trachea }\end{array}$ & $\begin{array}{l}\text { Main } \\
\text { bronchus }\end{array}$ & $\begin{array}{l}\text { Lower lobe } \\
\text { bronchus }\end{array}$ \\
\hline 'Incidental' & bronchitics & & & \\
10 & 310 & 622 & 296 & \\
11 & 555 & 341 & 209 & \\
12 & 225 & 406 & 118 & \\
13 & 218 & 526 & 183 & \\
14 & 234 & 608 & 209 & \\
& & & & \\
& 308 & 501 & 203 & Grand mean \\
'Fatal' bronchitics & & & \\
15 & 14 & 57 & 29 & \\
15 & 42 & 170 & 157 & \\
17 & 35 & 105 & 139 & \\
18 & 392 & 313 & 59 & \\
19 & 28 & 276 & 23 & \\
20 & 5 & 94 & 70 & \\
& 86 & 169 & 79 & \\
& & & &
\end{tabular}

in the same range as the subjects with severe chronic bronchitis.

\section{IgG, IgM, IgE CELL COUNTS}

The numbers of cells containing IgG, IgM, and IgE in subjects with 'fatal' bronchitis were not significantly different from those of normal subjects. As a result of their reduced numbers, $\operatorname{IgA}$ cells did not predominate in 'fatal' bronchitics to the same extent as in normal subjects.
EFFECT OF AGE AND INTERVAL BETWEEN DEATH AND FIXATION OF TISSUE

There did not appear to be a relationship between age and the IgA cell counts, nor between the cell counts and the interval between death and fixation of tissue (Figs 5 and 6).

\section{SERUM IgA}

Serum samples were not taken from these subjects but, in order to estimate whether the non-smoking subject with fatal chronic bronchitis (subject 20) had a systemic deficiency of $\operatorname{IgA}$, IgA and albumin were estimated by immunodiffusion in an extract from homogenised tracheal tissue; the IgA : albumin ratio was $1: 60$. This estimate, although crude, suggests that the serum IgA was not reduced and may have been raised.

\section{PARAFFIN SECTIONS}

Examination of paraffin sections of tissues adjacent to those examined by immunofluorescent methods showed mucus gland hypertrophy in all subjects. The gland/wall ratio (Reid, 1960) of the 'incidental' chronic bronchitics ranged from 0.50 to 0.70 , and those of the 'fatal' bronchitics from 0.40 to 0.69 , these being consistent with the diagnosis of chronic bronchitis in both groups.

\section{SPUTUM IgA}

Estimates of the proportion of the sputum which was locally secreted in 57 samples from 14 subjects are set out in Table 4 and Figure 7. In nine 


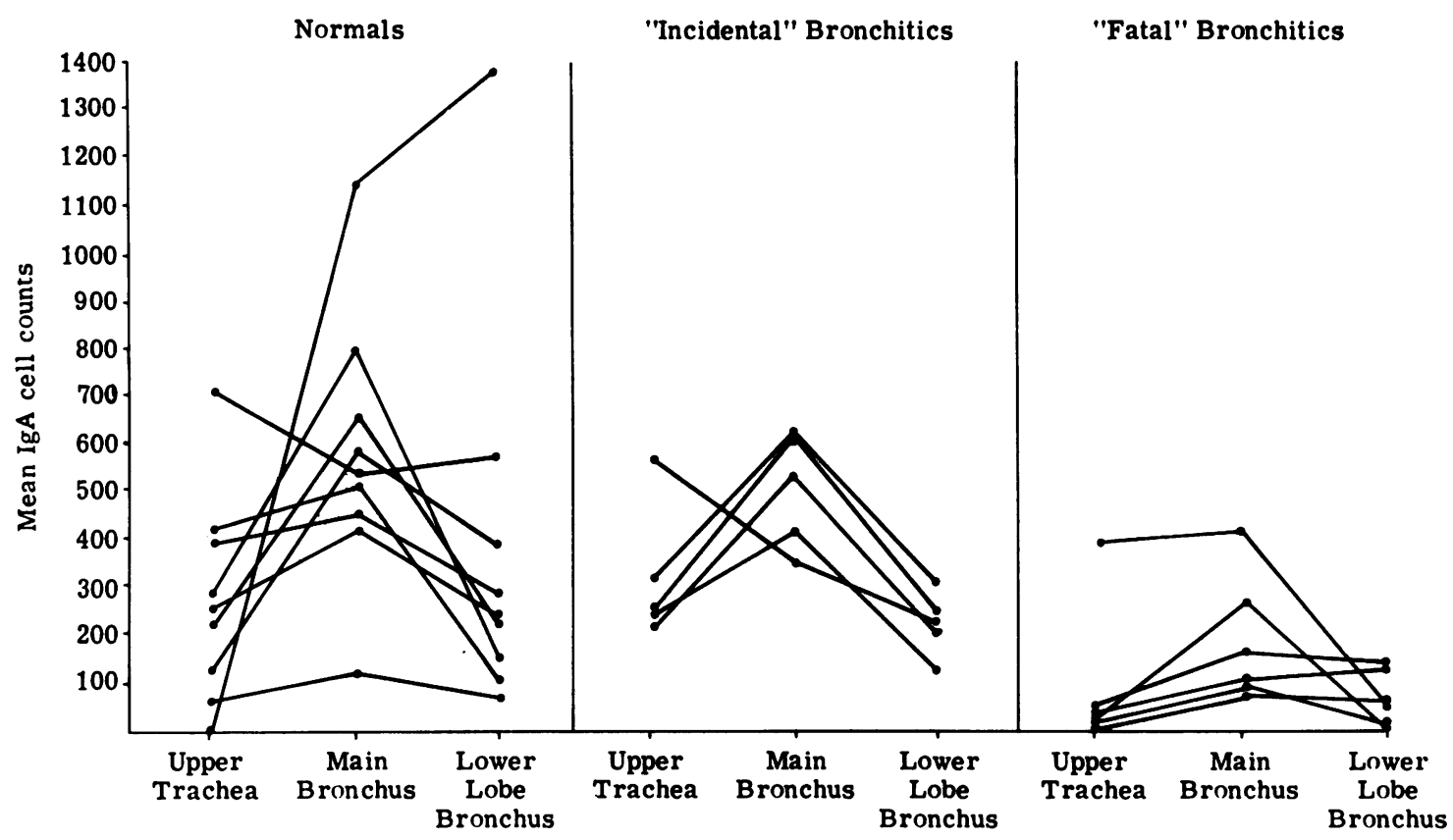

Fig. 3 Mean $\operatorname{IgA}$ cell counts at three sites in five 'incidental' chronic bronchitics and six 'fatal' chronic bronchitics. (Each point represents the mean of cell counts on four sections.)

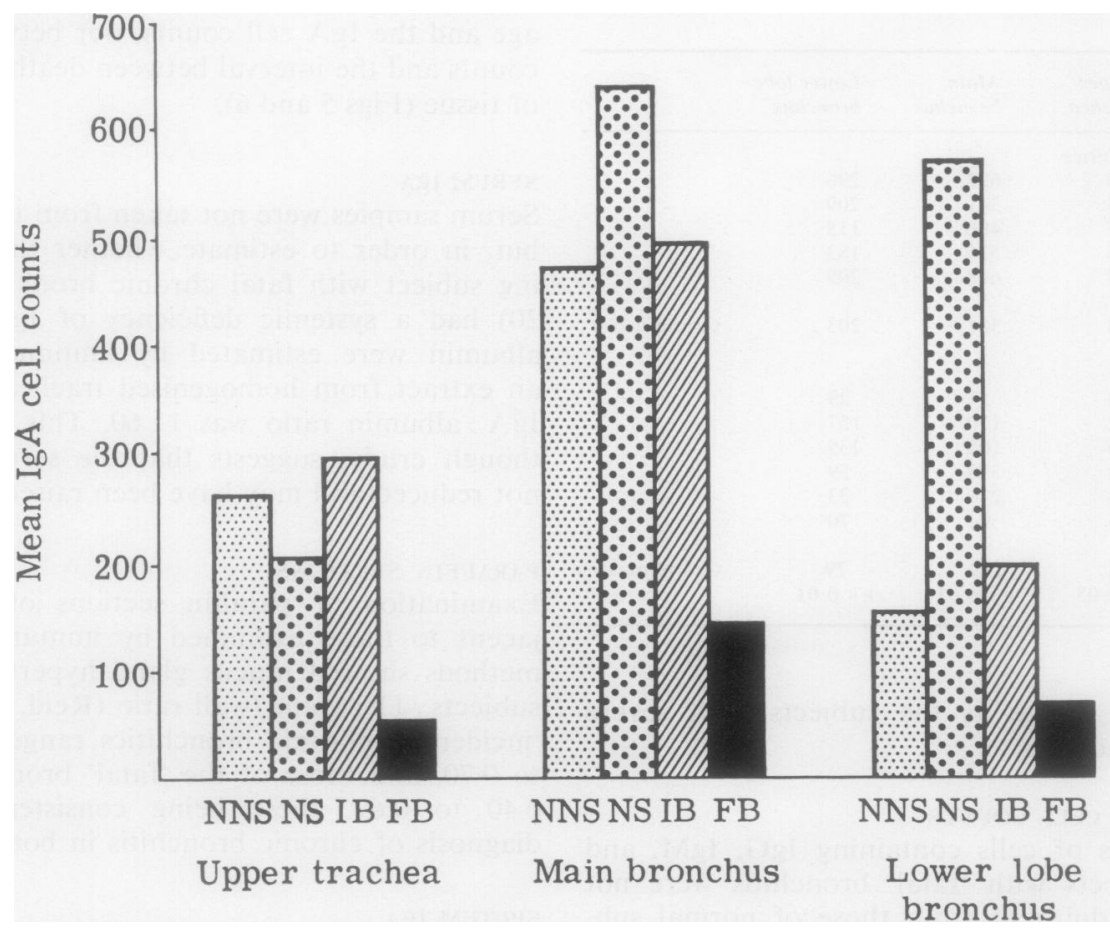

Fig. 4 Overall mean IgA cell counts at three sites in five normal non-smokers (NNS), four normal smokers (NS), five 'incidental' bronchitics (IB), and six 'fatal' bronchitics $(F B)$. Means are actually square mean roots. 


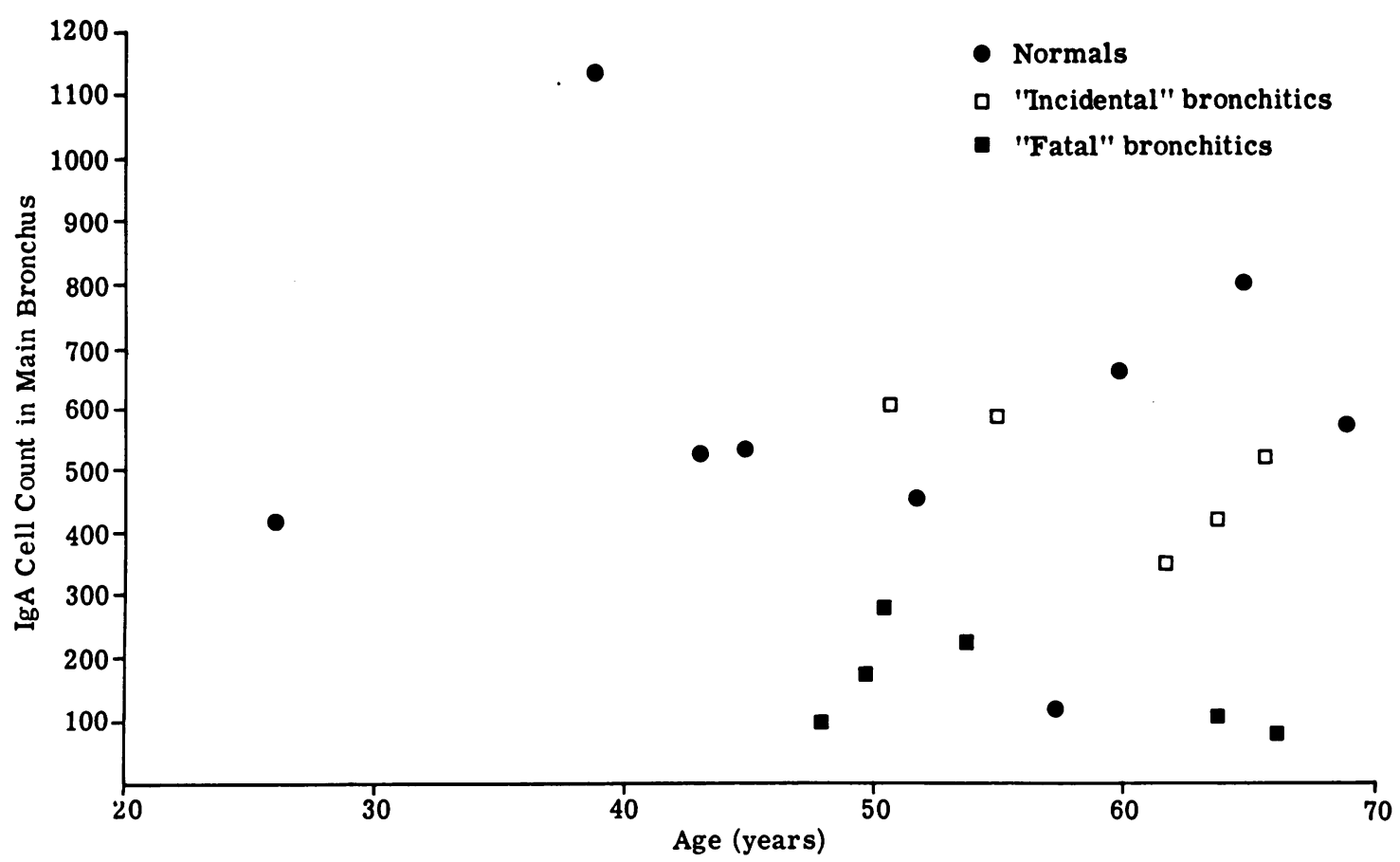

Fig. 5 Comparison between IgA cell counts at main bronchus with the age of the subject (nine normals and 11 chronic bronchitics).

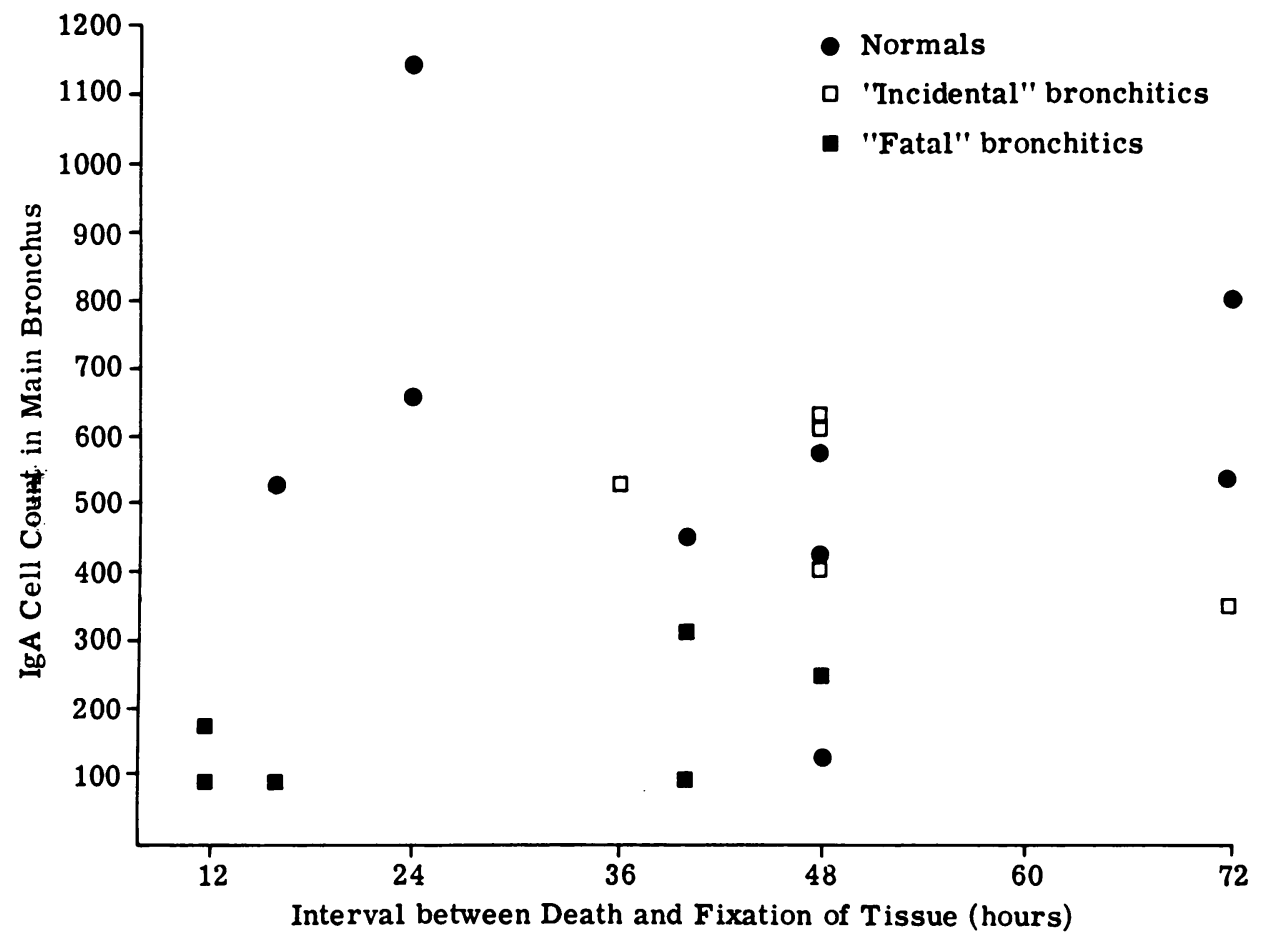

Fig. 6 Comparison between IgA cell counts at main bronchus with the interval between death and fixation of tissue (nine normals and 11 chronic bronchitics). 
Table 4 Estimations of local bronchial contribution of immunoglobulin in the sputum of 14 subjects with severe chronic bronchitis

\begin{tabular}{|c|c|c|c|c|c|c|}
\hline \multirow[t]{2}{*}{ Subject } & \multirow[t]{2}{*}{ Age } & \multirow{2}{*}{$\begin{array}{l}\text { No. of } \\
\text { estimations }\end{array}$} & \multirow{2}{*}{\multicolumn{2}{|c|}{ Material }} & \multicolumn{2}{|c|}{ Local secretion $(\%)$} \\
\hline & & & & & $\operatorname{Ig} .4$ & $I g G$ \\
\hline \multirow[t]{2}{*}{1} & 62 & 2 & Sputum & & 92 & 0 \\
\hline & & & , & & 87 & 0 \\
\hline \multirow[t]{4}{*}{2} & 59 & 4 & ," & & 56 & 10 \\
\hline & & & , & & 78 & 56 \\
\hline & & & ,. & & 85 & 61 \\
\hline & & & , & & 80 & 46 \\
\hline \multirow[t]{3}{*}{3} & 67 & 3 &, & & 93 & 7 \\
\hline & & & , & & 91 & 9 \\
\hline & & & , & & 97 & 18 \\
\hline \multirow[t]{2}{*}{4} & 46 & 2 & , & & 86 & 0 \\
\hline & & & , & & 84 & 0 \\
\hline \multirow[t]{4}{*}{5} & 59 & 4 & ., & & 96 & 0 \\
\hline & & & , & & 96 & 0 \\
\hline & & & , & & 97 & 0 \\
\hline & & & , & & 98 & 22 \\
\hline \multirow[t]{3}{*}{6} & 70 & 3 &, & & 86 & 0 \\
\hline & & & , & & 87 & 0 \\
\hline & & &, & & 89 & 0 \\
\hline \multirow[t]{3}{*}{7} & 74 & 3 & , & & 86 & 0 \\
\hline & & & , & & 80 & 0 \\
\hline & & & ," & & 82 & 0 \\
\hline \multirow[t]{3}{*}{8} & 68 & 3 & , & & 92 & 40 \\
\hline & & & $"$ & & 92 & 38 \\
\hline & & & , & & 66 & 40 \\
\hline \multirow[t]{2}{*}{9} & 41 & 2 &, & & 92 & 1 \\
\hline & & & , & & 93 & 14 \\
\hline \multirow[t]{5}{*}{10} & 65 & 5 & Bronchia & & 0 & 0 \\
\hline & & & ,, & ," & 0 & 0 \\
\hline & & & Sputum & 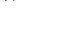 & 16 & 0 \\
\hline & & & , & & 25 & 0 \\
\hline & & & , & & 36 & 0 \\
\hline \multirow[t]{7}{*}{11} & 55 & 7 & , & & 56 & 0 \\
\hline & & & Bronchia & irate & 37 & 0 \\
\hline & & & ," & , & 0 & 0 \\
\hline & & & Sputum & (n & 0 & 0 \\
\hline & & & , & & 11 & 0 \\
\hline & & & ," & & 44 & 0 \\
\hline & & & , & & 88 & 0 \\
\hline 12 & 55 & 11 & , & & 62 & 0 \\
\hline & & & , & & 0 & 0 \\
\hline & & & , & & 0 & 0 \\
\hline & & & , & & 0 & 0 \\
\hline & & & , & & 0 & 0 \\
\hline & & & , & & 71 & 0 \\
\hline & & & , & & 83 & 0 \\
\hline & & & , & & 66 & 0 \\
\hline & & &, & & 87 & 0 \\
\hline & & & ,' & & 72 & 0 \\
\hline & & & , & & 87 & 0 \\
\hline 13 & 75 & & ," & & 69 & 31 \\
\hline & & & , & & 55 & 29 \\
\hline & & & , , & & 60 & 42 \\
\hline & & & ,, & & 44 & 15 \\
\hline 14 & 46 & 4 & Bronchia & irate & 46 & 0 \\
\hline & & & ", & , & 0 & 0 \\
\hline & & & , & , & 32 & 0 \\
\hline & & & , & , , & 44 & 0 \\
\hline
\end{tabular}

IgA values in subjects 1-9 were $>70 \%$ except for one estimation in subjects 2 and 8 . In subjects $10-14, \operatorname{lgA}$ values were $<70 \%$ on three or more occasions.

subjects the local IgA was greater than $70 \%$ (or fell below this value on only one occasion), but in the other five subjects the local IgA contribution was less than $70 \%$ on three or more occasions. In this latter group, there were striking fluctua- tions in the percentage of local $\operatorname{IgA}$ in the sputum, which in many cases appeared to show a progressive fall and subsequent rise through the period of illness. In four of the subjects the local IgA percentage actually fell to nil before rising again as the illness resolved.

In only five of the subjects was there active secretion of IgG. In the other nine, all the IgG in the sputum could be accounted for by serum IgG. No relationship was demonstrated between bronchial IgA secretion and sputum purulence.

\section{Discussion}

The results reported here demonstrate a deficiency of IgA within plasma and other cells in the lungs of a small group of subjects with fatal chronic obstructive bronchitis. This might represent a failure of production of $\operatorname{IgA}$ or an excessive depletion by, for instance, bronchial infection. Little is known of the normal morphology of IgA plasma cells in the respiratory tract after infection, although children who had died of cystic fibrosis with respiratory infection have been reported to have an excess of $\operatorname{IgA}$ cells in the respiratory tract (Martinez-Tello et al., 1968).

This contrasts strongly with our findings in fatal chronic bronchitis and suggests that there may have been a defect of IgA production in the lungs of these patients. The view is consistent with the work of Medici and Buergi (1971), who found that severe chronic bronchitics did not increase their IgA in response to infection, unlike subjects with mild bronchitis in whom a rise and fall of sputum IgA did occur. Deuschl and Johansson (1974), on the basis of a comparison of $\operatorname{IgA}$ and albumin levels in bronchial washings and serum from two chronic bronchitics, concluded that most of the IgA in the bronchial secretions was derived from serum, local production making a much smaller contribution than in normal subjects (in whom the local production of IgA was over $80 \%$ ), and our preliminary and more detailed studies in this laboratory, using a similar technique on sputum from 14 subjects with very severe chronic obstructive bronchitis, have shown a deficiency of bronchial IgA secretions during infective episodes in five subjects.

While it is possible that this apparent deficiency of IgA secretion was induced by an outpouring of serum exudate so that the sputum was largely composed of serum, it is at least consistent with the hypothesis that there is a deficiency of bronchial IgA secretion in a proportion of patients with severe chronic bronchitis. In some this ap- 


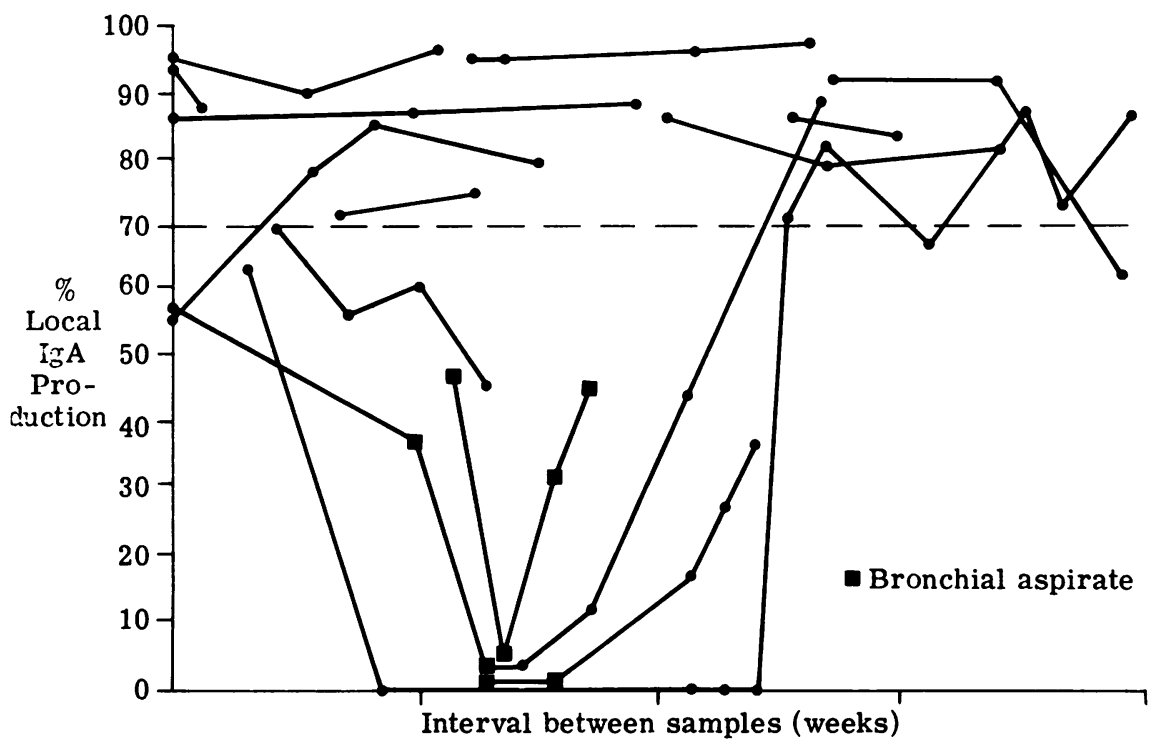

Fig. 7 Random estimations of bronchial IgA secretion in 14 chronic bronchitic subjects. Separation along the $X$ axis is for the purposes of visual clarity. Intervals between samples are correct.

pears to be a transient event but in others it persists. The transience of the deficiency seen in some subjects during exacerbations may be the result of exhaustion of the bronchial secretory IgA system, which can nevertheless secrete small amounts of $\operatorname{IgA}$ in the resting state but fails to increase it in response to infections. The appearances of the bronchial IgA plasma cells in 'fatal' bronchitis, which, in addition to being few in number, characteristically have only a thin rim of cytoplasm around the nucleus, would be consistent with this.

These findings suggest that the apparent bronchial IgA deficiency found in our small group of 'fatal' bronchitics may be common among those suffering from this disease. More detailed studies over longer periods of time are now required.

The cell counts for subjects with 'incidental' chronic bronchitis were in the same range as for normal non-smokers, but were slightly lower than for normal smokers in the lobar bronchus. This finding was supported by the impression of there being $\operatorname{IgA}$ cells round fewer small bronchi and bronchioles in 'incidental' bronchitics than in normals.

It would not necessarily be correct to assume that the IgA cell population in the respiratory tract of a smoker progresses through the four stages demonstrated by these groups of normal non-smokers, normal smokers, 'incidental' bronchitics, and 'fatal' bronchitics (that is, an initial increase in plasma cells, followed by a depression) although this sequence of events may occur. In vitro studies have been reported in which high concentrations of tobacco smoke products inhibit the production of antibody by lymphoid cells (Roszman and Rogers, 1973), and in man the salivary IgA has been reported to be depressed in healthy cigarette smokers (Lewis et al., 1970). In mice, cigarette smoke has been shown initially to stimulate the primary immune response but subsequently to depress it (Thomas et al., 1974).

Two of the subjects studied, one normal smoker and one 'fatal' bronchitic who never smoked, appear to have had normal amounts of IgA in their serum and a deficiency of $\operatorname{IgA}$ in the respiratory tract.

A pre-existing bronchial IgA deficiency conceivably may have predisposed the chronic bronchitics to develop severe and eventually fatal disease (through the medium of unrestrained tissue damaging infections), but the existence of the other, quite healthy, subject indicates that this factor alone is not necessarily sufficient to cause disease, and other factors such as smoking, atmospheric pollution, specific infectious agents or associated immune defects are also important.

I thank Professor Margaret Turner-Warwick for a great deal of advice and encouragement and Dr. 
G. Hinson and Professor R. D. Teare for much help in obtaining necropsy material. The Tobacco Research Council generously provided financial support. I also thank Mr. P. Townsend for technical assistance; the routine hospital laboratory staff for the serum immunoglobulin estimations; Mrs. Cherry Shabbo for secretarial help; Miss R. Pegus and the Department of Medical Art, Royal Marsden Hospital for the illustrations; and Mr. K. Moreman and the Department of Photography, Royal Marsden Hospital for the photographs.

This paper contains material forming part of a thesis submitted to the University of London for the degree of Doctor of Medicine. The work was done at the Cardiothoracic Institute at the Brompton Hospital, London.

\section{References}

Biegel, A. A., and Krumholz, R. A. (1968). An immunoglobulin abnormality in pulmonary emphysema. American Review of Respiratory Disease, 97, 217-222.

Biserte, G., Havez, R., and Cuvelia, R. (1963). Les glycoprotéides des sécrétions bronchiques. Exposés Annuels de Biochimie Médicale, 24, 85-120.

Deuschl, H., and Johansson, S. G. O. (1974). Immunoglobulins in tracheobronchial secretions with special reference to IgE. Clin. exp. Immunology, 16, 401412.

Falk, G. A., Okinaka, A. J., and Siskind, G. W. (1972). Immunoglobulins in the bronchial washings of patients with chronic obstructive pulmonary disease. American Review of Respiratory Disease, 105, 14-21.

Falk, G. A., Siskind, G. W., and Smith, J. P., Jr. (1970). Immunoglobulin elevations in the serum of patients with chronic bronchitis and emphysema. Journal of Immunology, 105, 1559-1562.

Fry, J. (1954). Chronic bronchitis in general practice. British Medical Journal, 1, 190-194.

Lewis, D. M., Lapp, N. L., and Burrell, R. (1970). Quantitation of secretory immunoglobulin $A$ in chronic pulmonary disease. American Review of Respiratory Disease, 101, 55-61.

Mancini, G., Carbonara, A. O., and Heremans, J. F. (1965). Immunochemical quantitation of antigens by single radial immunodiffusion. Immunochemistry, 2, 235-254.

Martinez-Tello, F. J., Braun, D. G., and Blanc, W. A. (1968). Immunoglobulin production in bronchial mucosa and bronchial lymph nodes, particularly in cystic fibrosis of the pancreas. Journal of Immunology, 101, 989-1003.

Medical Research Council Committee on the Aetiology of Chronic Bronchitis (1965). Definition and classification of chronic bronchitis. Lancet, 1, 775779.

Medici, T. C., and Buergi, H. (1971). The role of immunoglobulin $\mathrm{A}$ in endogenous bronchial defence mechanisms in chronic bronchitis. American Review of Respiratory Disease, 103, 784-791.

Northam, B. E., and Widdowson, G. M. (1967). Determination of serum albumen by autoanalyzer using bromocresol green. Technical Bulletin No. 11. Association of Clinical Biochemists Scientific and Technical Committee.

Oswald, N. C., Harold, J. T., and Martin, W. J. (1953). Clinical pattern of chronic bronchitis. Lancet, 2, 639-643.

Reid, L. (1960). Measurement of the bronchial mucous gland layer: a diagnostic yardstick in chronic bronchitis. Thorax, 15, 132-141.

Roszman, T. L., and Rogers, A. S. (1973). The immunosuppressive potential of products derived from cigarette smoke. American Review of Respiratory Disease, 108, 1158-1163.

Simon, G. (1971). Principles of Chest $X$-ray Diagnosis, 3rd ed. p. 51. Butterworths, London.

Soutar, C. A. (1976). Distribution of plasma cells and other cells containing immunoglobulin in the respiratory tract of normal man and class of immunoglobulin contained therein. Thorax, 31, 158166.

Thomas, W. R., Holt, P. G., and Keast, D. (1974). Development of alterations in the primary immune response of mice by exposure to fresh cigarette smoke. International Archives of Allergy and Applied Immunology, 46, 481-486.

Requests for reprints to: Dr. C. A. Soutar, Assistant Professor of Medicine, University of Illinois at the Medical Center, 840 South Wood Street, Chicago, Illinois, 60680 USA. 